\title{
ВИЗНАЧЕННЯ ОСОБИСТІСНИХ ЧИННИКІВ РОЗВИТКУ КОМУНІКАТИВНИХ ВЛАСТИВОСТЕЙ ПІДЛІТКІВ
}

\section{Павленко Тетяна Валерївна}

Аспірант Інституту психології імені Г. С. Костюка Національної академії педагогічних наук України, Київ (Україна)

\begin{abstract}
Аннотация. Стаття присвячена дослідженню особистісних якостей підлітків, які можуть виступати в якості чинників, щзо впливають на розвиток в них комунікативних властивостей. Вибірку було розділено за віковим та статевим критеріями, щзо дозволило отримати більш достовірні дані про розвиток комунікативних властивостей в підлітковому віці. За результатами дослідження було визначено 8 чинників, які в різній мірі впливають на розвиток комунікативних якостей у молодших та старших підлітків. До групи позитивних чинників, тобто таких, рівень розвитку яких треба підвищувати, віднесено рівень розвитку емпатії, потребу у спілкуванні, спрямованість на комунікацію, емочійну стабільність. До негативних - дратівливість, рівень самоконтролю, сенситивність, сором'язливість.
\end{abstract}

Ключевъе слова: комунікативні властивості, позитивні чинники, негативні чинники, особистісні якості, підлітковий вік, комунікація.

Актуальність дослідження. В сучасному суспільстві спілкування відіграє ще більше значення. Саме завдяки вмінню взаємодіяти з іншими людьми людина отримує можливість навчатись, засвоювати необхідний досвід, реалізувати себе у суспільстві. Важливу роль комунікативні навички відіграють у підлітковому віці. Це пов'язано з переходом до нового життєвого етапу, коли відбувається самоідентифікація особистості. Саме спілкування допомагає підлітку зрозуміти свою роль у колективі, визначити, які б якості він хотів у собі розвивати, а також навчитись встановляти зв'язки з оточуючими.

Підлітковий вік є перехідним етапом в житті особистості. В цей час починається статеве дозрівання і психологічне дорослішання дитини. У самосвідомості відбуваються значні зміни: з'являється відчуття дорослості - відчуття себе дорослою людиною $є$ центральним новоутворенням підліткового віку. В цей період відбуваються якісні зміни в емоційній та інтелектуальній сфері, формується новий рівень самосвідомості. У підлітка виникає пот- 


\section{ISSN 2414-004X (Online)}

реба у самоствердженні, рівноправному і довірливому спілкуванні з дорослими и ровесниками. Виникає пристрасне бажання якщо не бути, то хоч би здаватися і вважатися дорослим. Відстоюючи свої нові права, підліток захищає багато сфер свого життя від контролю батьків і часто йде на конфлікти з ними [4].

Вивчення чинників розвитку комунікативних властивостей у підлітковому віці дозволить розробити більш ефективні програми розвитку особистості і полегшити рівень iï соціалізації.

\section{Аналіз останніх досліджень і публіка-} цій.

Г. М. Андреєва визначає спілкування як процес взаємодії між двома чи кількома особами, який передбачає обмін між ними інформацією пізнавального та емоційнооцінного характеру, під час якого суб'єктивний світ однієї людини розкривається для іншої [1]. Спілкування є невіддільною і загальною умовою формування особистості підлітка. Саме в спілкуванні відбувається процес соціалізації та становлення. Комунікацію ж визначають як поняття, близьке до спілкування, але ширше за об'ємом. Комунікація між людьми відбувається у формі спілкування як обмін цілісними знаковими утвореннями (повідомленнями), в яких відображаються знання, думки, ідеї, ціннісні стосунки, емоційні стани, програми діяльності сторін, що спілкуються.

Вивченням комунікативних властивостей займалися О. О. Леонтьєв,
№ 1 (11) 2018

С. Д. Максименко, К. К. Платонов, Б. М. Теплов, К Роджерс. Саме вони наголошують на тому, що комунікативні навички є найважливішим чинником самореалізації особистості в підлітковому віці.

Спілкування - це соціальне середовище, яке дає можливість дитині повноцінно розвиватись. Саме спілкування допомагає дитині стати повноцінним членом суспільства, сприяє становленню іiї індивідуальності, самоактуалізації та особистісного росту [4]. Особливо важливу роль спілкування відіграє в підлітковому віці, оскільки є умовою успішного особистісного розвитку школярів.

Від комунікативної активності особис-

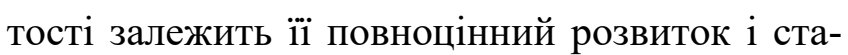
новлення. Саме завдяки вмінню спілкуватись 3 оточуючим, взаємодії з ними, відбувається формування моральних норм та цінностей [3]. Комунікація у підлітковому віці присутня у всіх сферах діяльності. Тим не менш, щоб мати можливість здійснювати комунікативні акти, необхідно мати певні вміння та навички. В процесі навчання повинна бути заздалегідь визначена цільова установка на формування комунікативної компетентності особистості, методи та засоби формування іiі формування [2].

Визначення особистісних якостей, які впливають на розвиток комунікативних властивостей у підлітковому віці дозволить розробити якісну програму, що відкриє нові можливості розвитку комунікації в заявленій віковій групі. 
Мета статті полягає у викладені результатів дослідження особистісних чинників розвитку комунікативних властивостей підлітків.

У досліджені прийняло участь 203 учня віком від 12 до 15 років, СШ 29 та ЗОШ 75 м. Кривий Ріг.

Для діагностики рівня розвитку комунікативних навичок підлітків було обрано наступні методики: тест «Комунікативні та організаторські схильності» В.В. Синявский, В. О. Федорошин (КОС), Фрайсбургський багатофакторний особистісний опитувальник FPI (шкала V - комунікабельність).

Для виявлення особистісних чинників, які впливають на розвиток комунікативних властивостей підлітка, було обрано наступні методики: Фрайсбургський багатофакторний особистісний опитувальник FPI Форма А., методика багатофакторного дослідження особистості Кеттела / Підлітковий варіант, тест для визначення потреби у спілкуванні (ПС) (Ю. М. Орлов, В. І. Шкуркін, Л. І Орлова, 1974), тест-опитувальник самоставлення (В. В. Столін, С. Р. Пантелеєв), методика експрес-діагностики емпатії Юсупова, тест «Оцінка самоконтролю у спілкуванні» Маріона Снайдера.

Для визначення чинників розвитку комунікативних якостей досліджуваних, було застосовано процедуру кореляційного аналізу (за Спірменом) результатів психодіагностичних методик та експертного оцінювання рівня розвитку комунікативних якостей учнів. Було проаналізовано 44 діагностичні показники, серед яких, за даними теоретичного аналізу, в якості внутрішніх чинників комунікативних властивостей підлітків, можуть виступати наступні 14: рівень самоповаги, рівень аутосимпатії, рівень комунікативного самоконтролю, рівень самоконтролю, потреба у спілкуванні, рівень розвитку емпатії, дратівливість, емоційна стабільність, сором'язливість, спрямованість на комунікацію (екстраверсіяінтраверсія), домінантність, ступінь прийняття моральних норм, сенситивність, залежність від думки оточуючих (конформізмнонконформізм). А також три шкали, які допомагають визначити рівень розвитку комунікативних властивостей у підлітковому віці.

На початковому етапі кореляційного дослідження, було проаналізовано всю вибірку, що дало змогу виявити особистісні якості підлітків, які мають найсильніший зв'язок 3 рівнем розвитку комунікативних властивостей (таблиця 1).

Отже, найтісніший позитивний зв'язок серед використаних діагностичних показників 3 рівнем розвитку комунікативних властивостей підлітків мають такі якості особистості як потреба у спілкуванні, рівень розвитку емпатії та емоційна стабільність. Тобто, зі збільшенням рівня розвитку цих якостей, збільшується рівень розвитку комунікативних властивостей. Виражений негативний зв'язок 3 рівнем розвитку комунікативних властивостей мають такі 
Таблиия 1.

\section{Кореляційні зв'язки рівня розвитку комунікативних властивостей підлітків та особистісних якостей $(\mathrm{n}=\mathbf{2 0 3})$}

\begin{tabular}{|c|c|c|c|c|c|c|c|}
\hline \multirow[t]{2}{*}{ № } & \multirow[t]{2}{*}{ Показник } & \multicolumn{2}{|c|}{$\begin{array}{c}\text { Рівень розвитку комуніка- } \\
\text { тивних здібностей }^{4}\end{array}$} & \multicolumn{2}{|c|}{ Комунікативність $^{6}$} & \multicolumn{2}{|c|}{ 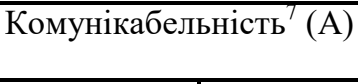 } \\
\hline & & $\mathrm{r}$ & $\mathrm{p} \leq$ & $\mathrm{r}$ & $\mathrm{p} \leq$ & $\mathrm{r}$ & $\mathrm{p} \leq$ \\
\hline 1 & Самоповага $^{1}$ & 0,14 & 0,05 & 0,20 & 0,004 & 0,17 & 0,01 \\
\hline 2 & $\begin{array}{l}\text { Аутосимпа- } \\
\text { тія }\end{array}$ & 0,02 & - & 0,07 & 0,32 & 0,03 & - \\
\hline 3 & $\begin{array}{l}\text { Рівень кому- } \\
\text { нікативного } \\
\text { самоконтро- } \\
\text { лю }^{2} \\
\end{array}$ & $-0,22$ & 0,002 & $-0,23$ & 0,001 & $-0,1$ & 0,19 \\
\hline 4 & $\begin{array}{l}\text { Рівень само- } \\
\text { контролю7 Q3 }\end{array}$ & $-0,09$ & 0,215 & $-0,10$ & 0,14 & $-0,05$ & 0,52 \\
\hline 5 & $\begin{array}{l}\text { Потреба у } \\
\text { спілкуванні }^{3}\end{array}$ & 0,35 & 0,001 & 0,42 & 0,001 & 0,19 & 0,007 \\
\hline 6 & $\begin{array}{l}\text { Рівень розви- } \\
\text { тку емпатії }^{5}\end{array}$ & 0,37 & 0,001 & 0,43 & 0,001 & 0,14 & 0,06 \\
\hline 7 & $\begin{array}{l}\text { Дратівли- } \\
\text { вість }\end{array}$ & $-0,40$ & 0,001 & $-0,40$ & 0,001 & $-0,14$ & 0,44 \\
\hline 8 & $\begin{array}{l}\text { Емоційна } \\
\text { стабільність }{ }^{7} \\
\text { (C) }\end{array}$ & 0,21 & 0,003 & 0,21 & 0,002 & 0,24 & 0,001 \\
\hline 9 & $\begin{array}{l}\text { Соромязли- } \\
\text { вість } 6\end{array}$ & $-0,24$ & 0,001 & $-0,24$ & 0,001 & $-0,20$ & 0,005 \\
\hline 10 & $\begin{array}{l}\text { Екстраверсія- } \\
\text { iнтраверсія }^{6} \\
\end{array}$ & $-0,11$ & 0,1 & 0,13 & 0,06 & 0,07 & 0,33 \\
\hline 11 & $\begin{array}{l}\text { Домінант- } \\
\text { ність }^{7} \mathrm{E} \\
\end{array}$ & $-0,09$ & 0,18 & $-0,1$ & 0,16 & $-0,10$ & 0,14 \\
\hline 12 & $\begin{array}{l}\text { Ступінь } \\
\text { прийняття } \\
\text { моральних } \\
\text { норм }^{7} \mathrm{G} \\
\end{array}$ & 0,01 & - & $-0,01$ & - & $-0,07$ & 0,29 \\
\hline 13 & $\begin{array}{l}\text { Сенситив- } \\
\text { ністьвність }^{7} \text { I }\end{array}$ & $-0,05$ & 0,45 & $-0,07$ & 0,35 & $-0,01$ & 0,9 \\
\hline 14 & $\begin{array}{l}\text { Конформізм- } \\
\text { нонконфомі- } \\
\text { 3м }{ }^{7} \text { Q2 }\end{array}$ & $-0,16$ & 0,03 & $-0,17$ & 0,01 & $-0,04$ & - \\
\hline
\end{tabular}

(Дані були отримані за наступними методиками: 1 - тест - опитувальник самоставлення (Століна), 2 тест «оиінка самоконтролю в спілкуванні» (по Маріону Снайдеру), 3 - тест для визначення потреби у спілкуванні (ПС) (Ю.М. Орлов), 4 - «комунікативні та організаторські схильності» В. В. Синявский, В. А. Федорочин (КОС), 5 - методика "Діагностика рівня емпатї̈, I. М. Юсупова, 6-фрайбургський багатофакторний особистісний опитувальник, 7 - тест-опитувальник Кеттела для підлітків).

якості як рівень комунікативного самоконтролю, дратівливість та сором'язливість. Тобто, зі зменшенням рівня розвитку цих якостей, рівень комунікативних властивостей підлітків збільшується.
Слабкий позитивний зв'язок 3 рівнем розвитку комунікативних властивостей у підлітків має рівень самоповаги. Тобто ця особистісна якість має незначний вплив на розвиток комунікативних властивостей у підлітковому 
віці. Слабкий негативний зв'язок мають такі показники як рівень загального самоконтролю, екстраверсія-інтраверсія (спрямованість на комунікацію), рівень сенситивності та автономності (конформізм-конформізм). Хоча наступними показниками як аутосимпатія та ступінь прийняття моральних норм. Тобто, ці показники не впливають на рівень розвитку комунікативних властивостей підлітків.

3 метою більш детального вивчен-

Таблиия 2.

Кореляційні зв'язки рівня розвитку комунікативних властивостей та особистісних якостей підлітків 12-13років $(\mathrm{n}=119)$

\begin{tabular}{|c|c|c|c|c|c|c|c|}
\hline \multirow[t]{2}{*}{ № } & \multirow[t]{2}{*}{ Показник } & \multicolumn{2}{|c|}{$\begin{array}{c}\text { Рівень розвитку } \\
\text { комунікативних }^{\text {здібностей }^{4}} \\
\end{array}$} & \multicolumn{2}{|c|}{ Комунікативність } & \multicolumn{2}{|c|}{$\begin{array}{l}\text { Комунікабель- } \\
\text { ність }^{7} \text { (А) }\end{array}$} \\
\hline & & $\mathrm{r}$ & $\mathrm{p} \leq$ & $\mathrm{r}$ & $\mathrm{p} \leq$ & $\mathrm{r}$ & $\mathrm{p} \leq$ \\
\hline 1 & Самоповага $^{1}$ & 0,09 & 0,33 & 0,12 & 0,18 & 0,07 & 0,47 \\
\hline 2 & Аутосимпатія ${ }^{\top}$ & 0,05 & - & $-0,01$ & 0,92 & 0,07 & 0,41 \\
\hline 3 & Рівень комунікативного самоконтролю ${ }^{2}$ & $-0,04$ & - & $-0,07$ & 0,43 & 0,02 & - \\
\hline 4 & Рівень самоконтролю' Q3 & $-0,16$ & 0,01 & $-0,22$ & 0,015 & 0,04 & - \\
\hline 5 & Потреба у спілкуванні ${ }^{3}$ & 0,51 & 0,001 & 0,53 & 0,001 & 0,12 & 0,2 \\
\hline 6 & Рівень розвитку емпатії & 0,34 & 0,001 & 0,37 & 0,001 & 0,1 & 0,3 \\
\hline 7 & Дратівливість $^{6}$ & $-0,21$ & 0,001 & $-0,31$ & 0,001 & 0,08 & 0,4 \\
\hline 8 & Емоційна стабільність ${ }^{\prime}$ (C) & 0,20 & 0,01 & 0,25 & 0,006 & 0,12 & 0,18 \\
\hline 9 & Соромязливість $^{6}$ & $-0,24$ & 0,01 & $-0,26$ & 0,005 & $-0,15$ & 0,10 \\
\hline 10 & Екстраверсія-інтраверсія $^{6}$ & 0,24 & 0,01 & 0,25 & 0,006 & 0,12 & 0,18 \\
\hline 11 & Домінантність $^{\top} \mathrm{E}$ & $-0,14$ & 0,13 & $-0,16$ & 0,08 & 0,12 & 0,21 \\
\hline 12 & Ступінь прийняття моральних норм $^{\prime} \mathrm{G}$ & 0,03 & - & 0,03 & - & 0,13 & 0,15 \\
\hline 13 & 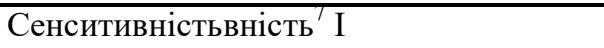 & $-0,06$ & 0,52 & $-0,05$ & 0,57 & 0,07 & 0,48 \\
\hline 14 & Конформізм-нонконфомізм ${ }^{\prime} \mathrm{Q}^{2}$ & $-0,15$ & 0,10 & $-0,22$ & 0,032 & 0,04 & - \\
\hline
\end{tabular}

(Дані були отримані за наступними методиками: 1 - тест - опитувальник самоставлення (Століна), 2 тест «оцінка самоконтролю в спілкуванні» (по Маріону Снайдеру), 3 - тест для визначення потреби у спілкуванні (ПС) (Ю. М. Орлов), 4 - «комунікативні та організаторські схильності» В. В. Синявский, В. А. Федорошин (КОС), 5 - методика "Діагностика рівня емпатї̈», I. М. Юсупова, 6 - фрайбургський багатофакторний особистісний опитувальник, 7 - тест-опитувальник Кеттела для підлітків).

ці якості мають незначний вплив на розвиток комунікативних властивостей у підлітків, їх варто враховувати при подальшому дослідженні.

Не виявлено кореляційних зв'язків 3 ня особистісних якостей, які можуть впливати на розвиток комунікативних властивостей підлітків, вибірку було розділено за віковим критерієм і проаналізовано кореляційні зв'язки між показниками підлітків 12-13 років 
(таблиця 2) та 14-15 років (таблиця 3).

Найтісніший позитивний зв'язок серед використаних діагностичних показників 3 рівнем розвитку комунікативних властивостей підлітків 12-13 років мають такі особистісні якості як потреба у спілкуванні, рівень розвитку емпатії, емоційна стабільність, спрямова- мають рівень самоконтролю, дратівливість, сором'язливість, домінантність.

Слабкий позитивний зв'язок 3 рівнем розвитку комунікації має рівень розвитку самоповаги, слабкий негативний - рівень залежності від думки оточуючих (конформізмнонкоформізм). Хоча ці показники не мають

Таблиця 3.

\section{Кореляційні зв'язки рівня розвитку комунікативних якостей та внутрішніх чинни-} ків підлітків 14-15років $(\mathbf{n}=84)$

\begin{tabular}{|c|c|c|c|c|c|c|c|}
\hline \multirow[t]{2}{*}{ № } & \multirow[t]{2}{*}{ Показник } & \multicolumn{2}{|c|}{$\begin{array}{c}\text { Рівень розвитку ко- } \\
\text { мунікативних здіб- } \\
\text { ностей }^{4}\end{array}$} & \multicolumn{2}{|c|}{ Комунікативність $^{6}$} & \multicolumn{2}{|c|}{$\begin{array}{l}\text { Комунікабельність' } \\
\text { (А) }\end{array}$} \\
\hline & & $r$ & $\mathrm{p} \leq$ & $r$ & $\mathrm{p} \leq$ & $\mathrm{r}$ & $\mathrm{p} \leq$ \\
\hline 1 & Самоповага $^{\top}$ & 0,17 & 0,12 & 0,27 & 0,01 & 0,29 & 0,01 \\
\hline 2 & Аутосимпатія $^{\top}$ & 0,07 & 0,51 & 0,13 & 0,23 & 0,16 & 0,16 \\
\hline 3 & $\begin{array}{l}\text { Рівень комунікативного само- } \\
\text { контролю }^{2}\end{array}$ & $-0,39$ & 0,001 & $-0,38$ & 0,001 & 0,21 & 0,05 \\
\hline 4 & Рівень самоконтролю ${ }^{7}$ Q3 & 0,01 & - & $-0,07$ & - & 0,06 & - \\
\hline 5 & Потреба у спілкуванні ${ }^{3}$ & 0,15 & 0,17 & 0,28 & 0,01 & 0,31 & 0,005 \\
\hline 6 & Рівень розвитку емпатії & 0,37 & 0,001 & 0,39 & 0,001 & 0,17 & 0,13 \\
\hline 7 & Дратівливість $^{6}$ & $-0,52$ & 0,001 & $-0,47$ & 0,001 & $-0,23$ & 0,03 \\
\hline 8 & Емоційна стабільність ${ }^{\prime}(\mathrm{C})$ & 0,24 & 0,03 & 0,29 & 0,007 & 0,33 & 0,002 \\
\hline 9 & Соромязливість $^{6}$ & $-0,24$ & 0,02 & $-0,22$ & 0,04 & $-0,26$ & 0,01 \\
\hline 10 & Екстраверсія-інтраверсія & $-0,08$ & 0,45 & $-0,06$ & 0,58 & $-0,02$ & - \\
\hline 11 & Домінантність $^{\top} \mathrm{E}$ & $-0,01$ & - & 0,02 & - & 0,08 & 0,47 \\
\hline 12 & $\begin{array}{l}\text { Ступінь прийняття моральних } \\
\text { норм }^{7} \mathrm{G}\end{array}$ & $-0,03$ & - & $-0,06$ & - & $\overline{-0,01}$ & - \\
\hline 13 & 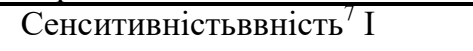 & $-0,05$ & - & $-0,01$ & 0,37 & $-0,08$ & 0,45 \\
\hline 14 & $\begin{array}{l}\text { Конформізм-нонконфомізм } \\
\text { Q2 }\end{array}$ & $-0,14$ & 0,19 & $-0,1$ & 0,03 & 0,04 & - \\
\hline
\end{tabular}

(Дані були отримані за наступними методиками: 1 - тест - опитувальник самоставлення (Століна), 2 тест «очінка самоконтролю в спілкуванні» (по Маріону Снайдеру), 3 - тест для визначення потреби у спілкуванні (ПС) (Ю. М. Орлов), 4 - «комунікативні та організаторські схильності» В. В. Синявский, В. А. Федорошин (КОС), 5 - методика «Діагностика рівня емпатї̈, I. М. Юсупова, 6 - фрайбургський багатофакторний особистісний опитувальник, 7 - тест-опитувальник Кеттела для підлітків).

ність на комунікацію (екстраверсія- вирішального впливу на розвиток комунікатиінтраверсія). Виражений негативний зв'язок з вних властивостей підлітка, тим не менш, їх рівнем розвитку комунікативних властивостей варто враховувати в дослідженні. 
Не мають зв'язку з рівнем розвитку комунікативних властивостей підлітків 12-13 років такі показники як аутосимпатія, ступінь прийняття моральних норм, рівень сенситив- у підлітків 14-15 років мають такі показники які рівень розвитку емпатії та емоційна стабільність. Виражений негативний зв'язок мають такі показники як рівень комунікативно-

Таблиия 4.

\section{Кореляційні зв'язки комунікативних властивостей та особистісних якостей дівчат у підліт- ковому віці $(\mathbf{n}=93)$}

\begin{tabular}{|c|c|c|c|c|c|c|c|}
\hline \multirow[t]{2}{*}{ № } & \multirow[t]{2}{*}{ Показник } & \multicolumn{2}{|c|}{$\begin{array}{c}\text { Рівень розвитку комунікатив- } \\
\text { них здібностей }\end{array}$} & \multicolumn{2}{|c|}{ Комунікативність $^{6}$} & \multicolumn{2}{|c|}{$\begin{array}{l}\overline{\text { Комунікабельність }} \\
\text { (А) }\end{array}$} \\
\hline & & $\mathrm{r}$ & $\mathrm{p} \leq$ & $\mathrm{r}$ & $\mathrm{p} \leq$ & $\mathrm{r}$ & $\mathrm{p} \leq$ \\
\hline 1 & Самоповага $^{1}$ & 0,16 & 0,14 & 0,17 & 0,1 & 0,13 & 0,21 \\
\hline 2 & Аутосимпатія & $-0,05$ & - & 0,01 & - & $-0,03$ & - \\
\hline 3 & $\begin{array}{l}\text { Рівень комунікати- } \\
\text { вного самоконт- } \\
\text { роль }\end{array}$ & $-0,13$ & 0,12 & $-0,13$ & 0,21 & $\overline{-0,01}$ & - \\
\hline 4 & $\begin{array}{l}\text { Рівень самоконт- } \\
\text { ролю } \\
7\end{array}$ & $-0,11$ & 0,32 & $-0,07$ & 0,5 & 0,11 & 0,3 \\
\hline 5 & $\begin{array}{l}\text { Потреба у спілку- } \\
\text { ванні }^{3}\end{array}$ & 0,49 & 0,001 & 0,5 & 0,001 & 0,15 & 0,16 \\
\hline 6 & $\begin{array}{l}\text { Рівень розвитку } \\
\text { емпатії }\end{array}$ & 0,24 & 0,02 & 0,38 & 0,001 & $-0,16$ & 0,12 \\
\hline 7 & Дратівливість $^{6}$ & $-0,37$ & 0,001 & $-0,39$ & 0,001 & $-0,16$ & 0,04 \\
\hline 8 & $\begin{array}{l}\text { Емоційна стабіль- } \\
\text { ність }{ }^{7} \text { (C) }\end{array}$ & 0,17 & 0,1 & 0,14 & 0,17 & 0,14 & 0,18 \\
\hline 9 & Соромязливість $^{6}$ & $-0,1$ & 0,36 & $-0,12$ & 0,3 & $-0,24$ & 0,02 \\
\hline 10 & $\begin{array}{l}\text { Екстраверсія- } \\
\text { iнтраверсія }^{6} \\
\end{array}$ & 0,29 & 0,005 & 0,31 & 0,003 & 0,1 & 0,4 \\
\hline 11 & Домінантність $^{\top}$ E & $-0,23$ & 0,03 & $-0,22$ & 0,03 & 0,13 & 0,2 \\
\hline 12 & $\begin{array}{l}\text { Ступінь прийняття } \\
\text { моральних норм }^{7} \\
\mathrm{G}\end{array}$ & 0,1 & 0,36 & 0,11 & 0,28 & 0,15 & 0,16 \\
\hline 13 & 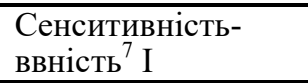 & 0,03 & - & $-0,03$ & - & 0,07 & 0,53 \\
\hline 14 & $\begin{array}{l}\text { Конформізм- } \\
\text { нонконфомізм }^{7} \text { Q2 }\end{array}$ & $-0,26$ & 0,012 & $-0,28$ & 0,007 & $-0,01$ & - \\
\hline
\end{tabular}

(Дані були отримані за наступними методиками: 1 - тест - опитувальник самоставлення (Століна), 2 тест «оцінка самоконтролю в спілкуванні» (по Маріону Снайдеру), 3 - тест для визначення потреби у спілкуванні (ПС) (Ю. М. Орлов), 4 - «комунікативні та організаторські схильності» В. В. Синявский, В. А. Федорошин (КОС), 5 - методика «Діагностика рівня емпатї̈», I. М. Юсупова, 6 - фрайбургський багатофакторний особистісний опитувальник, 7 - тест-опитувальник Кеттела для підітків).

ності.

Найтісніший позитивний зв'язок серед використаних діагностичних показників з рівнем розвитку комунікативних властивостей го самоконтролю, дратівливість та сором'язливість. Зі зменшенням рівня розвитку цих якостей у підлітків у віці 14-15 років, рівень розвитку комунікативних властивостей збіль- 
Таблиия 5.

\section{Кореляційні зв'язки комунікативних властивостей та особистісних якостей хлопців у підлітковому віці $(\mathbf{N}=110)$}

\begin{tabular}{|c|c|c|c|c|c|c|c|}
\hline \multirow[t]{2}{*}{ № } & \multirow[t]{2}{*}{ Показник } & \multicolumn{2}{|c|}{$\begin{array}{c}\text { Рівень розвитку комуніка- } \\
\text { тивних здібностей }^{4}\end{array}$} & \multicolumn{2}{|c|}{ Комунікативність $^{6}$} & \multicolumn{2}{|c|}{ 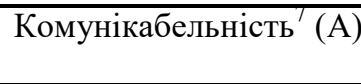 } \\
\hline & & $\mathrm{r}$ & $\mathrm{p} \leq$ & $\mathrm{r}$ & $\mathrm{p} \leq$ & $\mathrm{r}$ & $\mathrm{p} \leq$ \\
\hline 1 & Самоповага $^{1}$ & 0,13 & 0,16 & 0,26 & 0,006 & 0,2 & 0,04 \\
\hline 2 & Аутосимпатія & 0,1 & 0,31 & 0,2 & 0,04 & 0,07 & 0,45 \\
\hline 3 & $\begin{array}{l}\text { Рівень комунікатив- } \\
\text { ного самоконтролю }\end{array}$ & $-0,28$ & 0,003 & $\overline{-0,24}$ & 0,01 & $-0,11$ & 0,24 \\
\hline 4 & $\begin{array}{l}\text { Рівень самоконтро- } \\
\text { лю }^{7} \mathrm{Q} 3\end{array}$ & $-0,11$ & 0,27 & $-0,12$ & 0,2 & $-0,02$ & - \\
\hline 5 & $\begin{array}{l}\text { Потреба у спілкуван- } \\
\text { Hi }^{3}\end{array}$ & 0,22 & 0,02 & 0,3 & 0,002 & 0,23 & 0,02 \\
\hline 6 & $\begin{array}{l}\text { Рівень розвитку емпа- } \\
\text { тії }^{5}\end{array}$ & 0,42 & 0,001 & 0,43 & 0,001 & 0,15 & 0,13 \\
\hline 7 & Дратівливість $^{6}$ & $-0,4$ & 0,001 & $-0,4$ & 0,001 & $-0,07$ & 0,46 \\
\hline 8 & $\begin{array}{l}\text { Емоційна стабіль- } \\
\text { ність }^{7}(\mathrm{C})\end{array}$ & 0,3 & 0,002 & 0,34 & 0,001 & 0,27 & 0,004 \\
\hline 9 & Соромязливість $^{6}$ & $-0,4$ & 0,001 & $-0,4$ & 0,001 & $\overline{-0,11}$ & 0,27 \\
\hline 10 & $\begin{array}{l}\text { Екстраверсія- } \\
\text { iнтраверсія }^{6}\end{array}$ & $-0,03$ & - & 0,02 & - & 0,002 & - \\
\hline 11 & Домінантність $^{\top} \mathrm{E}$ & $-0,05$ & - & $-0,07$ & 0,47 & $-0,01$ & - \\
\hline 12 & $\begin{array}{l}\text { Ступінь прийняття } \\
\text { моральних норм }^{7} \mathrm{G}\end{array}$ & $-0,11$ & 0,25 & $-0,2$ & 0,04 & 0,11 & 0,28 \\
\hline 13 & $\begin{array}{l}\text { Сенситивністьвність }{ }^{\top} \\
\text { I }\end{array}$ & $-0,16$ & 0,1 & $-0,2$ & 0,04 & 0,01 & - \\
\hline 14 & $\begin{array}{l}\text { Конформізм- } \\
\text { нонконфомізм }^{7} \text { Q2 }\end{array}$ & $-0,07$ & 0,5 & $-0,05$ & - & 0,06 & 0,5 \\
\hline
\end{tabular}

(Дані були отримані за наступними методиками: 1 - тест - опитувальник самоставлення (Століна), 2 тест «оцінка самоконтролю в спілкуванні» (по Маріону Снайдеру), 3 - тест для визначення потреби у спілкуванні (ПС) (Ю. М. Орлов), 4 - «комунікативні та організаторські схильності» В. В. Синявский, В. А. Федорошин (КОС), 5 -методика "Діагностика рівня емпатії», I. М. Юсупова, 6- фрайбургський багатофакторний особистісний опитувальник, 7 - тест-опитувальник Кеттела для підлітків).

шується.

Слабкий позитивний зв'язок мають такі показники як самоповага, аутосимпатія, потреба у спілкуванні. Слабкий негативний конформізм-нонконформізм.

Не мають зв'язку з рівнем розвитку комунікативних властивостей такі особистісні якості як спрямованість на комунікацію (екстраверсія-інстраверсія), домінантність, ступінь прийняття моральних норм, сенситивність.

Порівнявши вибірку за віковим критерієм, було виявлено деякі спільні та відмінні риси. Спільним показником, який має сильний позитивний зв'язок у обох вікових групах $\epsilon$ емоційна стабільність. Спільним показником 3 
негативним зв'язком - сором'язливість. Тобто, складаючи програму розвитку комунікативних властивостей для підлітків, слід обов'язково враховувати ці два показники.

Не менш важливим моментом під час кореляційного дослідження стало порівняння розвитку комунікативної сфери у дівчат (таблиця 4) та хлопців (таблиця 5). 3 метою виявлення спільних та відмінних рис за статевою ознакою було додатково проведено кореляційний аналіз окремо всіх дівчат та всіх хлопців у вибірці.

Найтісніший позитивний зв'язок 3 рівнем розвитку комунікативних властивостей у дівчат-підлітків мають наступні показники: потреба у спілкуванні, рівень розвитку емпатії, спрямованість на комунікацію (екстраверсія-інтраверсія). Виражений негативний зв'язок мають показники дратівливість, домінантність, залежність від думки оточуючих (конформізм-нонкомформізм), зменшення рівня розвитку яких позитивно впливає на розвиток комунікації.

Слабкий позитивний зв'язок мають такі якості як самоповага та емоційна стабільність, слабкий негативний - рівень комунікативного і загального самоконтролю, рівень сором'язливості.

Не мають впливу на розвиток комунікативних властивостей у дівчат підліткового віку такі показники як аутосимпатія, ступінь прийняття моральних норм, сенситивність.

Наступним етапом нашого досліджен- ня, який допоможе краще зрозуміти особливості розвитку комунікативних властивостей підлітків, був кореляційних аналіз особистісних якостей всіх хлопців у вибірці (таблиця 5).

Найтісніший позитивний кореляційний зв'язок з рівнем розвитку комунікативних властивостей мають такі показники як потреба i спілкуванні, рівень розвитку емпатії, емоційна стабільність. Виражений негативний зв'язок мають такі показники як рівень комунікативного самоконтролю, дратівливість, сенситивність.

Слабкий позитивний зв'язок мають показники самоповага, аутосимпатія, слабкий негативний - рівень загального самоконтролю, ступінь прийняття моральних норм.

Не впливають на розвиток комунікативних властивостей такі показники як спрямованість на комунікацію (екстраверсіяінтраверсія), домінантність та залежність від думки оточуючих (конформізмнонконформізм).

Таким чином, ми бачимо значні відмінності у розвитку комунікативної сфери у дівчат та хлопців підліткового віку. У дівчат рівень спрямованості на комунікацію має істотний зв'язок з розвитком комунікативних властивостей, у хлопців такий зв'язок не відстежується. Це стосується і чинників з негативним зв'язком, таких як рівень комунікативного самоконтролю, сором'язливість та сенситивність, які у хлопців мають сильний зв'язок 3 рівнем розвитку комунікативних властивос- 
тей, а у дівчат цей зв'язок або слабкий, або зовсім не виражений.

У дівчат яскраво виражений негативний зв'язок між домінантністю та залежністю від думки оточуючих, для хлопців же ці показники не відіграють важливої ролі у розвитку комунікативних властивостей.

Висновки. Отримані результати дозволили визначити особистісні чинники, розвиток яких $\epsilon$ важливим для розвитку комунікативних властивостей підлітків. Можна виділити 2 групи чинників: позитивні (якості особистості, рівень розвитку яких треба підвищувати), та негативні (рівень розвитку яких варто нівелювати). До позитивних чинників варто віднести наступні: рівень розвитку емпатії, потреба у спілкуванні, спрямованість на комунікацію, емоційна стабільність. До негативних - p piвень дратівливості, рівень самоконтролю, сенситивність, сором'язливість. Важливо відмітити, що значимість цих чинників різна для хлопчиків та дівчат підліткового віку, тим не менше, їх варто враховувати при роботі з усіма категоріями підлітків.

\section{Перспектива подальших досліджень} полягає у розробці програми розвитку комунікативних властивостей, 3 урахуванням вищеперерахованих чинників, що дозволить сприяти більш якісному становленню особистості у підлітковому віці.

\section{Перелік використаних джерел:}

1. Андреєва Г. М. Социальная психология / Г. М. Андреєва. - М.: Изд-во Московського ун-та - 1980. - С. 97 -98 .

2. Винославська О. В. Розвиток практичної компоненти комунікативної компетентності студентів технічного університету / О.В. Винославська, Н.Г. Андрійченко // Практична психологія та соціальна робота. - 2004. - № 12. - C. 65-69.

3.Ісаєва О.В. Комунікативна компетентність та засоби корекції процесу спілкування підлітків / О. В. Ісаєва // Актуальні питання сучасної психології - 2014. - С. 7175

4. Самохвалова А. Г. Стимулирование коммуникативной активности детей в образовательном пространстве / А.Г. Самохвалова // Гуманізація навчально-виховного процесу. Збірник наукових праць. - 2012. - Вип. 10. C. 224-231.

\section{References (Transliteration):}

1. Andreeva G. M. Social'naja psihologija / G. M. Andre€va. - M.: Izd-vo Moskovs'kogo un-ta - 1980. -S. 97 -98 .

2. Vinoslavs'ka O. V. Rozvitok praktichnoï komponenti komunikativnoï kompetentnosti studentiv tehnichnogo universitetu / O.V. Vinoslavs'ka, N.G. Andrijchenko // Praktichna psihologija ta social'na robota. - 2004. - № 12. - S. 65-69.

3. Isaeva $O . V$. Komunikativna kompetentnist ta zasobi korekcii procesu spilkuvannja pidlitkiv / O. V. Isaeva // Aktual'ni pitannja suchasnoï psihologii. - 2014. - S. 71-75.

4. Samohvalova A. G. Stimulirovanie kommunikativnoj aktivnosti detej v obrazovatel'nom prostranstve / A.G. Samohvalova // Gumanizacija navchalno-vihovnogo procesu. Zbirnik naukovih prac. - 2012. - Vip. 10. - S. 224-231. 


\section{Pavlenko Tatiana}

PhD student of H. S. Kostyuk Institute of Psychology of the National Academy of Educational Sciences of Ukraine, Kyiv (Ukraine)

\section{DETERMINATION OF PERSONAL FACTORS OF PROGRESS OF COMMUNICATIVE QUALITIES OF TEENAGERS}

\section{ABSTRACT}

The article considers the role of communication as an important component of personality development in adolescence. Relevance is substantiated by the fact that communicative abilities are individual and psychological features of the individual, which are a condition for effective interaction with others. Studying of the factors of development of communicative properties will allow to develop more effective programs of development and to facilitate the level of socialization of a teenager.

The assumption is made that the development of communicative qualities is influenced by a number of personal factors, adjusting which can contribute to better development of teenager communicative. In order to verify this assumption, a program for the diagnosis of adolescents was developed, and the results of these studies are presented in the article in the form of tables.

The paper presents the results of the correlation analysis of the dependence of the development of communicative properties on the level of development of personality traits of a teenager. Primary consideration is given to the analysis of the entire sample, which allows us to follow the general trends in the development of the commu- nicative sphere in adolescence. In the following, the results of the sample analysis by age and gender criteria are presented and analyzed. Additionally, there are common and distinctive features of the development of the communicative sphere of teenagers of all ages (12-13 and 14-15 years), and the differences between boys and girls.

Thus, a number of personal qualities were identified that are factors that influence the development of communicative properties of teenagers. This will allow the development of a quality program that will open up new opportunities for communication development in the declared age group.

Key words: communicative qualities, positive factors, negative factors, personality traits, teenage age, communication.

\section{Павленко Татьяна Валерьевна}

Аспирант Института психологии имени Г. С. Костюка Национальной академии педагогических наук Украины, Киев (Украина)

\section{ОПРЕДЕЛЕНИЕ ЛИЧНОСТНЫХ ФАКТОРОВ РАЗВИТИЯ КОММУНИКАТИВНЫХ СВОЙСТВ ПОДРОСТКОВ}

Аннотация. В статье рассмотрена роль общения как важной составляющей развития личности в подростковом возрасте. Актуальность обосновывается тем, что коммуникативные способности являются индивидуальнопсихологическими особенностями личности, которые являются условием эффективного взаимодействия с окружающими. Изучение 
факторов развития коммуникативных свойств позволит разработать более эффективные программы развития и облегчить уровень социализации подростка.

Выдвинуто предположение, что на развитие коммуникативных качеств влияет ряд личностных факторов, корректируя которые можно способствовать лучшему развитию коммуникативности подростка. С целью проверки этого предположения была разработана программа диагностики подростков, а результаты этих исследований представлены в статье в виде таблиц.

В работе приведены результаты корреляционного анализа зависимости развития коммуникативных свойств от уровня развития личностных качеств подростка. Первоначально рассматриваются данные анализа всей выборки, что позволяет проследить общие тенденции развития коммуникативной сферы в подростковом возрасте. В дальнейшем представлены и проанализированы результаты анализа выборки по возрастному и половым критериям. Дополнительно представлены общие и отличительные черты развития коммуникативной сферы подростков разного возраста (12-13 и 14-15 лет) и различия по половому критерию.

Таким образом, был выделен ряд личностных качеств, которые являются фактора- ми, влияющими на развитие коммуникативных свойств подростков. Это позволит разработать качественную программу, откроет новые возможности развития коммуникации в заявленной возрастной группе.

Ключевые слова: коммуникативные свойства, личностные качества, подростковый возраст, коммуникация. 